\title{
Anna Gardocka-Jałowiec
}

University of Białystok

e-mail: a.gardocka@uwb.edu.pl

ORCID: 0000-0003-3281-1513

\section{Katarzyna Wierzbicka}

University of Białystok

e-mail: k.wierzbicka@uwb.edu.pl

ORCID: 0000-0002-4158-778X

\section{BARRIERS TO CREATING INNOVATION IN THE POLISH ECONOMY IN THE YEARS 2012-2016}

\begin{abstract}
The purpose of the considerations is to present and systematise barriers to creating innovation in the Polish economy in 2012-2016. The desk research was based on the results of Community Innovation Surveys (CIS 2012 and CIS 2014), thematic studies of the Central Statistical Office and a report from the Infuture hatalska foresight institute. The use of statistical and comparative analysis in conjunction with the review of the literature on innovation barriers leads to the conclusion that Polish enterprises recognise the lack of financial resources as a major barrier to creating innovation, while non-financial barriers are much less important. The marginal treatment of non-financial barriers is a reversal of attitudes and directions of activities that are undertaken in the field of creating innovation in highly developed countries.

Keywords: innovations, creation of innovations, barriers to innovation, Poland, CIS 2012, CIS 2014.
\end{abstract}

JEL: O31, O32, O39

\section{Introduction}

Innovation is the product of conscious human activity focused on achieving something new to meet an objective goal within a specific environment. This process is never carried out in subjective and temporal isolation. It is based on the ability of business entities to recognise the value of new information, concepts and ideas, and to absorb and transform them into other concepts and ideas. It is connected with the previous tendency and the ability of individuals to be active in this area. It is an integrated pro- 
cess the essence of which is a systematic analysis of the possibilities and constraints that can be revealed in the near and distant surroundings of the enterprise.

Considering the fact that most of the innovation work focuses on factors that increase their success, the purpose of the considerations was to present and systematise the barriers to creating innovation in the Polish economy in 2012-2016. The area of interest included Polish industrial enterprises and those operating in the services sector whose innovation activity was presented in comparison with EU countries. For the needs of the considerations, secondary data was used. The desk research was based on the results of the Community Innovation Surveys (CIS 2012 and CIS 2014) carried out by national statistical offices in the European Union countries, thematic studies of the Central Statistical Office and the report from the Infuture hatalska foresight institute entitled Handbook: Jak wdrażać innowacje? [How to implement innovations?] (Handbook, 2018).

The attempt to identify and analyse the barriers to the creation of innovations is intended to draw the attention of practitioners and the scientific community to their important place in the formulation and implementation of strategies by Polish enterprises.

\section{Creating innovations}

The process of creating innovations is a sequential series of changes in accordance with certain assumptions and values, leading to a new way of production, thinking and creation. The importance of innovations for the development of civilisation strengthened with the development of discussions conducted since the times of Pigou, Wicksell, Schumpeter or Solow. The neoclassical theory of development and technical progress was limited in principle to the analysis of process innovations. The increase in labour productivity was seen mainly in the accumulation of physical capital, underestimating the importance of human (intellectual) capital, new products or new forms of organisation (Schmookler, 1966: 3). However, the conviction that the well-being of the state depends to a large extent on its natural resources, and that business activity is mainly determined by material and human resources, began to lose its validity. In the second half of the $20^{\text {th }}$ century, discussions about economic and social development dominated the topic of innovation.

Approaches to creating innovations and factors determining the effectiveness of this process have evolved from a purely technological approach 
to a social one the essence of which is openness to the individual, a deeper understanding of consumer needs and expectations regarding the level and quality of life. R. Rothwell identified five generations of the innovation model and the next significant changes, which were observed in the methods of creating innovation at the beginning of the $21^{\text {st }}$ century, gave rise to the next models, i.e. the sixth and the seventh generations.

According to Rothwell, the first generation model of innovation was driven by science (supply-side model) which dominated until the mid-1960s. The second generation model is a model of market-driven innovation (demand model) that prevailed until the early 1970s. In the 1970s the interaction model was dominant (coupling model), while to the late 1980s it was an integrated model. The fifth generation model prevailing in the 1990s is a simultaneous (network) model which Rothwell calls the systems integration and networking model (Rothwell, 1992: 221). The first two generations of models present the process in a linear perspective and show an emphasis on one of the aspects of creating innovation. Models of subsequent generations are non-linear, complex models. They are characterised by the existence of relationships between demand and supply conditions for the emergence of innovation as well as feedbacks between their individual stages.

At the beginning of the $21^{\text {st }}$ century changes in the methods of creating innovations by enterprises resulted in the separation of the sixth generation model known as the open innovation model (Du Preez, Louw, Essmann, 2015; Brem 2011: 14; Dymitrowski, 2014: 35). The specificity of the innovation creation process is combining the paths of generating ideas, i.e. merging ideas developed by the enterprise and the network in which it operates with ideas coming from the market, external entities operating independently. In this model an important place is attributed to network or online communities. It is recognised that open innovation requires new logic. Such approach puts openness and cooperation at the centre of attention. The advantage of open innovation is therefore a much larger database of ideas, technologies and inspiring opportunities for development.

Although the sixth generation of the innovation model is still relatively new, attempts are being made to identify the seventh generation model. The seventh generation model combines models of open and network innovations, creating an integrated innovation network. The specificity of the new, only identified, approach to creating innovation is the assumption that in order to fully use all concepts of open innovation, enterprises should develop integrated knowledge networks for the development of innovation (Dymitrowski, 2014: 35). 
The increase in the share of social component (social change) in innovation models is an expression of the transition from closed innovations to open ones. The concept of open innovations is based on the diversity of knowledge, skills and social competences, i.e. the values coming from within the enterprise and its environment. Innovations are not only a direct result of scientific research, the involvement of centres conducting $\mathrm{R}+\mathrm{D}$ activity and other entities active in innovation. They are also created by stakeholders, end users and consumers. Knowledge capital plays an important role in creating open innovations.

Changes in the model approach to creating innovations, occurring over the last decades, indicate that the innovative change is a cumulative process which means that new activities in this area are systematically added to what has been implemented and achieved. The task of the business entities is to discover those areas of knowledge that are compatible with the activities and achievements already implemented (Zielińska-Głębocka, 1996: 101).

\section{Barriers to creating innovation - literature review}

As Pellegrino and Savona note (2017: 510-521), most of the innovation work focuses on factors that increase their success and not on those that constrain the innovation activity. However, every active and potential innovator can face the appearance of constraints in any part of the process of creating innovation which in consequence may lead to a failure of the undertaking. Identification and analysis of possible innovation constraints can be helpful in identifying all obstacles that constrain the rate and efficiency of innovation implementation. Undeniably, their identification is essential for the development of any enterprise.

The word "barrier" can be understood as "an issue that either prevents or hampers innovative activities in the firm" (Sandberg, Aarikka-Stenroos, 2014: 1294). In the literature it is combined with such terms as e.g. bottlenecks, constraints, challenges, fears, threats, difficulties, obstacles and problems. Barriers hamper, hinder or complicate the creation of innovations and, therefore, lead to a failure in innovative activity.

The evolution of the creation process of innovation corresponds to the development of the approach to its constraining factors. In addition to the financial barrier, a group of non-financial barriers has emerged. Financial barriers are seen as one of the main constraints of innovation. These include undercapitalisation, short-term liquidity problems, insufficient working capital, insufficient initial capital and poor financial management (Larsen, 
Lewis, 2007: 142-151). Although financial sources are key to success in developing and introducing a new product or service, they do not guarantee success in innovation (Cassamatta, 2003: 2059-2085).

Another division of barriers commonly used in research is the division into internal and external barriers. Hözl and Junger (2011), Sandberg and Aarikka-Stenroos (2014: 1294) indicate that internal barriers relate to the organisation, management and competence of the enterprise, while external barriers refer to obstacles caused by the market, government and system and result from interaction with other companies or institutions.

Internal barriers to creating innovation relate to the company's leadership, mentality and other human factors. They are considered in the aspect of the way of thinking, resources, organisational structure and competence ${ }^{1}$. Sandberg and Aarikka-Stenroos (2014: 1294) noticed that the restrictive mentality is the dominant barrier for SMEs and large enterprises, while the lack of competence refers to the generation of ideas (in the case of large enterprises), incubation (in the case of SMEs).

In relation to external barriers it is worth mentioning that they can be considered in two categories, i.e. as external barriers corresponding to obstacles that result from the behaviour of a specific actor and as external barriers combined with a macro environment ${ }^{2}$.

Hözl and Junger (2011) also undertake research into barriers to creating innovation in the system of external, financial and human barriers (Maldonado-Guzmán, Garza-Reyes, Pinzón-Castro, Kumar, 2017: 16691686). In addition, they indicate that large and prosperous enterprises may encounter the following barriers in the process of creating innovation:

- adoption barriers that limit firms' capability to explore new disruptive innovation, leading to an increase of excessive bureaucracy;

- mindset barriers which are related to the fact that innovative companies are stuck in the stagnant way in which products and markets work and, consequently, do not allow the use of potential opportunities;

- thinking and management limitations (no more ideas).

A different approach to the barriers to creating innovation is proposed by D'Este et al. (2012: 482-488). They distinguish between their two groups. The first group of barriers is related to the political perspective. It concerns entities responsible for creating formal institutions. According to the authors, the activity of these actors should focus on creating conditions conducive to innovative activity, identifying the reasons for the lack of innovation as well as anticipating adverse phenomena. The second group of barriers according to D'Este et al., connects with the perspective of innovation management in the enterprise. 
Anna Gardocka-Jałowiec, Katarzyna Wierzbicka

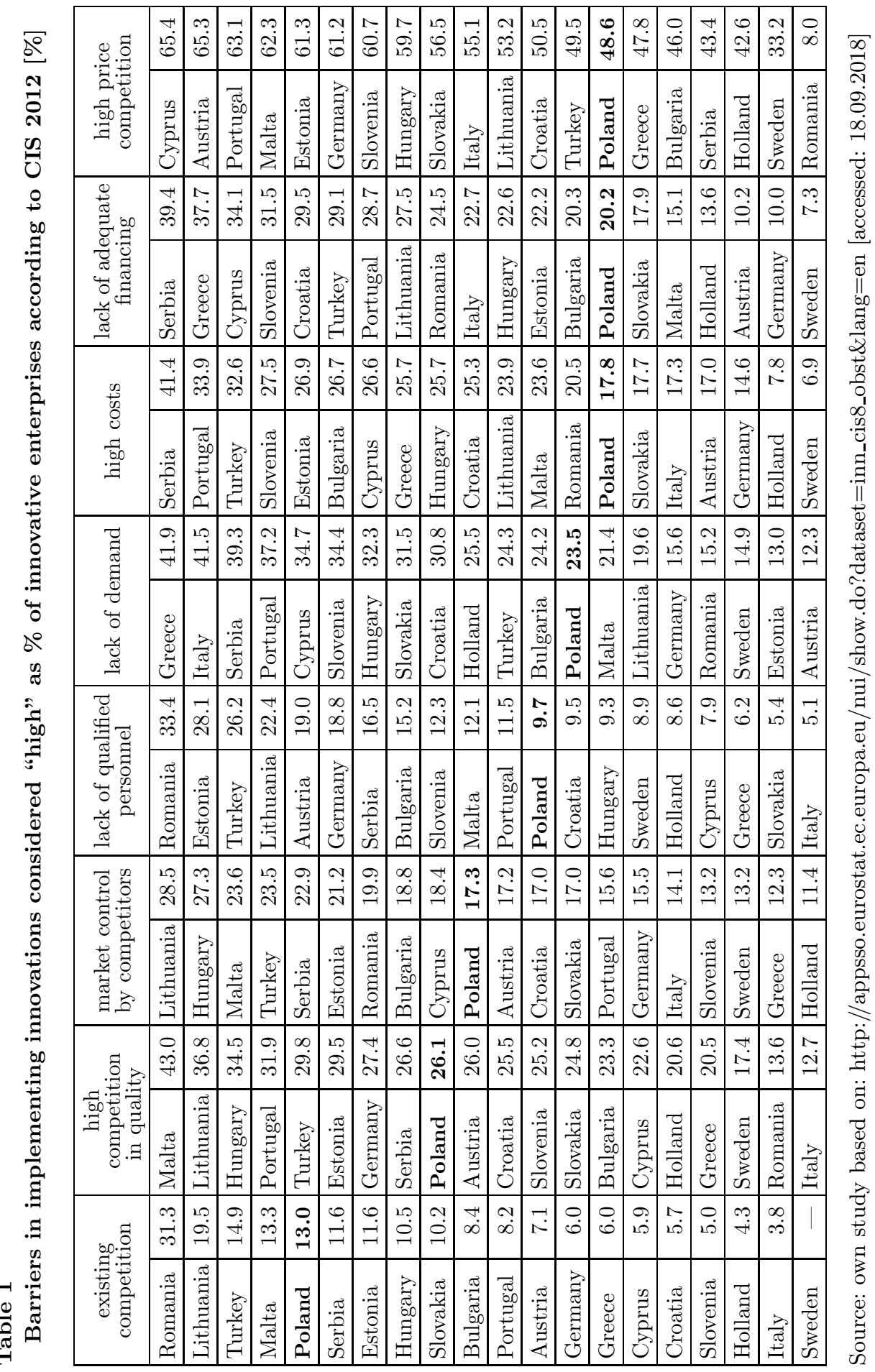




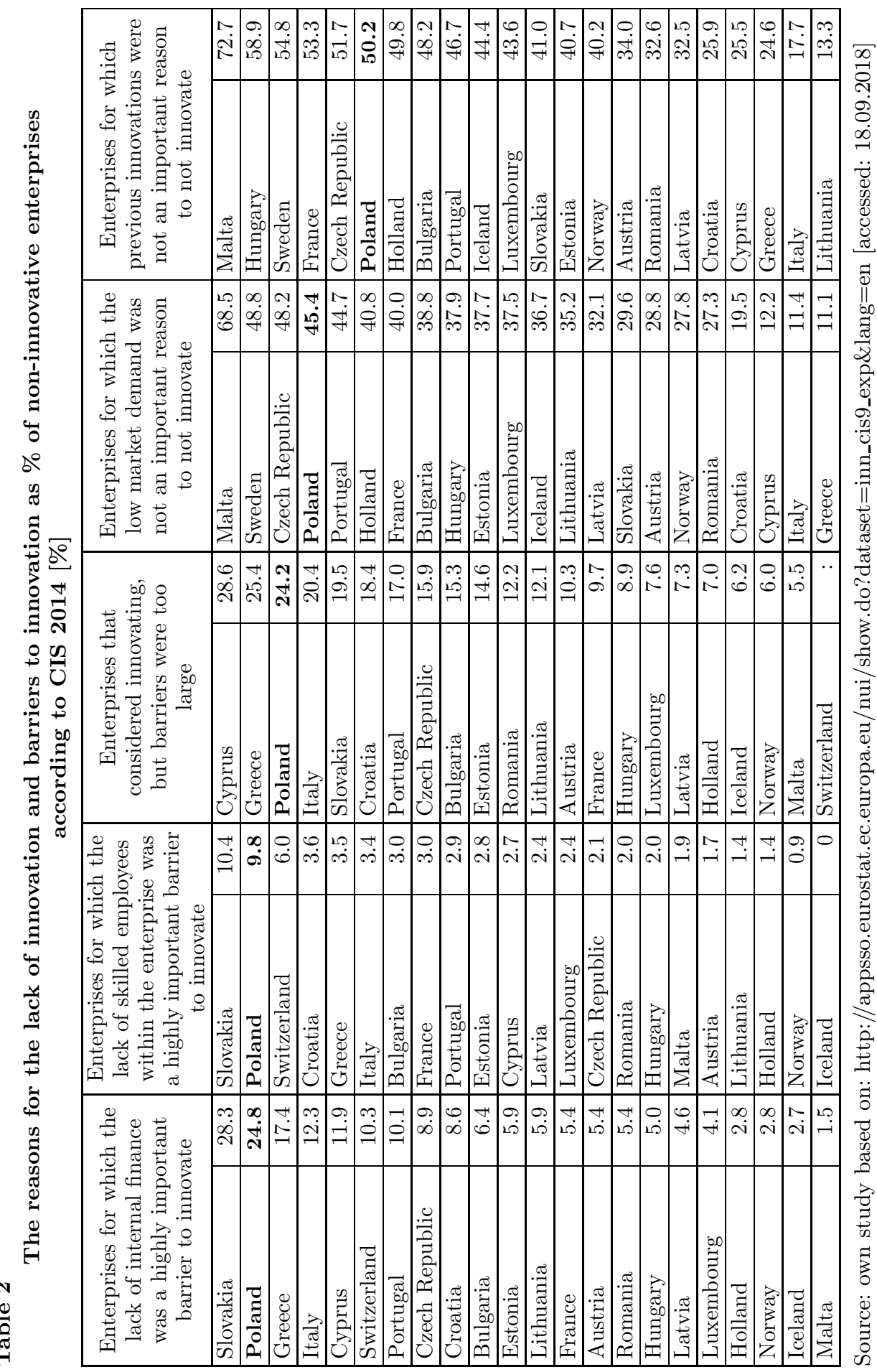


Anna Gardocka-Jałowiec, Katarzyna Wierzbicka

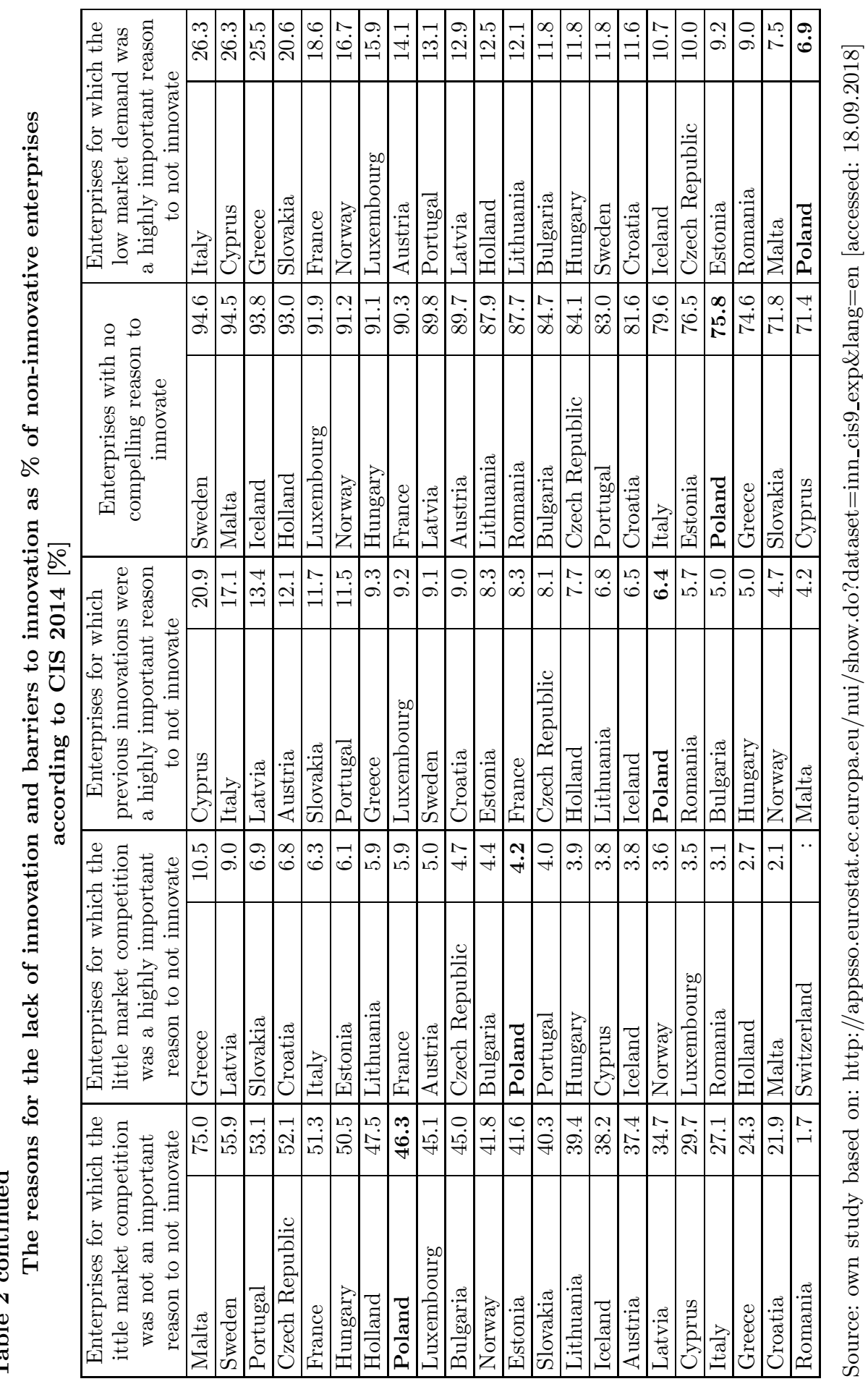


The classification of barriers to functional and psychological ones is also noteworthy (Lian, Yen, 2013: 665-672). Psychological barriers are associated with beliefs, imaginations and attitudes of entities acquiring innovations with respect to the country of origin, brand, industry and culture. The group of functional barriers includes:

- usage barriers - the lack of compatibility between the innovation introduced on the market and consumer's expectations;

- value barriers - the new product is not clearly better than the existing one which does not encourage the consumer to buy, recognise its value;

- risk barriers - combine with caution and distrust of the consumer towards offered innovations.

Concluding deliberations on the classification of barriers to the creation of innovation, the change in the approach to their identification should be stressed. It turns out that important information is provided by the analysis based on the division of enterprises into innovative and non-innovative ones.

Research on barriers to creating innovation from the perspective of innovative and non-innovative enterprises has been conducted, among others, by Hölzl and Junger (2014). In 2014 the results of the Community Innovation Survey (CIS), which are based on methodological recommendations contained in the Oslo Manual, were based on responses from non-innovative enterprises, while in CIS 2012 innovative enterprises were the basis (see tables 1 and 2).

\section{Barriers to create innovation in Poland in 2012-2016 - desk research}

According to the latest Community Innovation Survey (CIS 2014), Polish non-innovative enterprises, among the factors constraining innovative activity, highly evaluate the lack of internal financing (24.8\%) and the lack of qualified employees (9.8\%). The low demand on the market is considered the least important. Whereas according to CIS 2012, in which innovative enterprises were surveyed, the highest rank was attributed to the existence of competition on the market. Subsequently, the lack of demand and adequate financing was indicated. The least important constraint was the lack of qualified personnel.

The indicated constraints are important from the point of view of launching an innovative product or process into the market. According to Pellegrino et al., this possibility is reduced by $7 \%$ in case of financial 
obstacles, by $4.7 \%$ in case of presence of market constraints and by $2.6 \%$ in the face of regulatory obstacles (Pellegrino, Savona, 2017).

CSO research carried out in 2012-2016 on a group of non-innovative enterprises indicates that financial constraints are the main reason for the lack of innovation activity. The highest percentage of non-innovative industrial enterprises (on average 19\% in the analysed period) and service companies (nearly $12 \%$ ) pointed to the lack of financing opportunities from internal sources. Similarly, the external financing options were perceived (on average $13 \%$ of non-innovative industrial enterprises and $9 \%$ of service enterprises). Non-innovative service enterprises also recognised the difficulty in obtaining public grants or subsidies (over $8 \%$ ) as a similar constraint, while industrial enterprises indicated the lack of demand. Other equally important barriers included finding partners for cooperation and qualified employees.

The presented research results of Polish enterprises indicate that among barriers to creating innovation financial barriers are highly rated. One of the conditions for the efficient creation of innovation is the proper recognition of the external environment. The stimulus to the creation of innovation, as P. F. Drucker states, does not have to be a technological factor, often observations of the market, demographic processes and social attitudes are enough. However, it should be emphasised that the ability to identify changes in the environment is not a sufficient condition. According to the theory of absorptive capacity (Ettlie, 2000: 83); Zastempowski, 2010: 88-90), the information obtained from external sources requires internal processing, taking actions leading to its use in practice.

Therefore, creating innovation is basically about a human being. His attitudes, skills, competences, flexibility of adaptation and openness to changes are important, which are revealed at various stages of the process of creating innovation. Resistance to innovation that employees pose can be conditioned by risk and change (Sitkowska, 2006: 40-41). The introduction of innovations infringes to some extent the safety of employees. They may feel the depreciation of their own qualifications, the decline in the prestige of the job, the loss of their current position in the enterprise, or the loss of jobs in the event of failure of the company's innovative activity. As a result, the level of individual concern can lead to resistance to change, i.e. constraint of the innovative activity.

Undoubtedly, the indicated barriers should be considered important and their inclusion in the formulation and implementation of the strategy of the activities of Polish enterprises is emphasised by the results of a survey carried out in October and November 2017 by Infuture hatalska foresight institute. Quantitative research indicates three main barriers to creating in- 


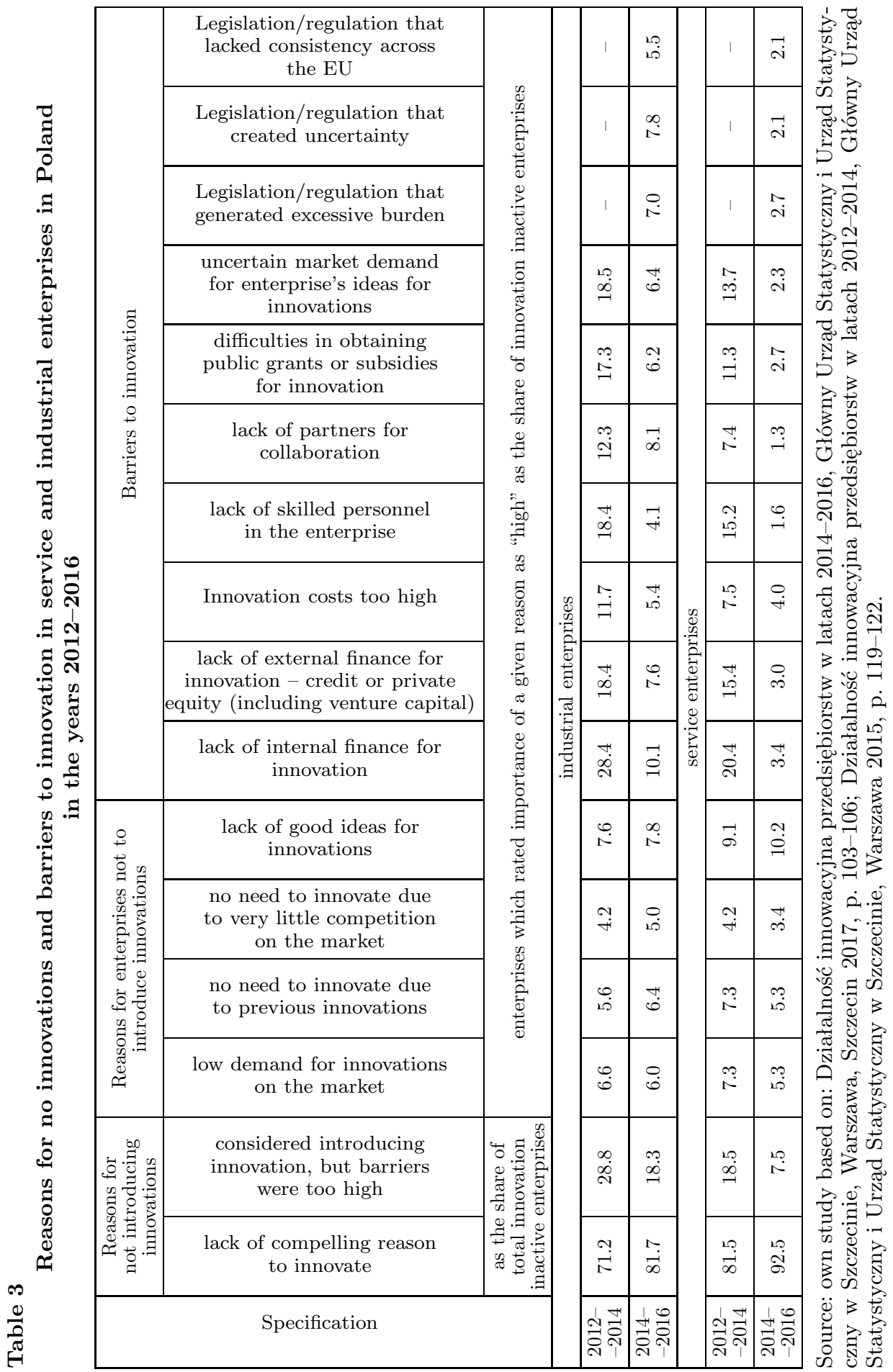


novation, i.e. too heavy workload for employees/managers with current tasks (69\% of surveyed enterprises), lack of capital/insufficient capital to finance innovation (47\%) and organisational difficulties (32\%) (Handbook, 2018). In contrast, qualitative research allows to identify the specificity of activities and decisions of Polish enterprises that clearly do not support innovation. They indicate (Handbook, 2018):

- eliminating innovations that bring value but for which it is difficult to clearly identify a measurable financial result, the scale profit;

- equating innovation and fast profit. Building optimistic financial forecasts and anticipating that innovations will start earning in the first year;

- concentrating on solutions and not on problems and needs;

- lack of an alternative action plan in case of failure;

- too rigid or too diffused innovation process;

- excessive proceedings and decisions making process at subsequent levels;

- lack of space for making mistakes and failures (the conviction that every innovation must be a success);

- too narrow tracking of trends, observing only their market, focusing only on their products, brands.

The quoted results of the qualitative study in correspondence with the results of qualitative research allow to conclude that bridging the barriers to creating innovation in Polish enterprises should be fostered by establishing cooperation. Building a network of "innovation coalition partners" - both within the company and the network of partners and contractors will be conducive to gathering and sharing knowledge, creating teams with diverse competences and various experiences. As a consequence, the sense of security and responsibility for innovations in the aspect not only non-financial but also financial will increase.

\section{Conclusion}

Polish enterprises recognise the financial barrier as the main obstacle to creating innovation. They pay less attention to non-financial factors, including market ones. However, they are equally important. Modern, highly developed societies function in the era of open innovation and strive for economic activity that will lead to a lasting improvement of the quality of life of not only present but also future generations.

Taking into account the conducted desk research, including the attempt to systematise the barriers to creating innovation, it can be concluded that 
the marginal treatment of non-financial barriers is a reversal of attitudes and directions of actions undertaken in highly developed and innovative countries. The specificity of the innovation creation process is combining the paths of generating ideas, i.e. merging ideas developed by the enterprise and the network in which it operates, with ideas coming from the market, external entities acting independently.

In Poland innovative activity is fundamentally based on the diffusion of innovation not on the creation of new innovations. The change in this state should be fostered by taking actions anticipating and counteracting the intensification of non-financial barriers. The specificity of the innovation creation process is combining the paths of generating ideas, i.e. merging ideas developed by the enterprise and the network in which it operates, with ideas coming from the market, external entities acting independently. Creating innovations requires from business entities (innovators, consumers) the ability to recognise phenomena and ideas, convert them into new values (in the form of products, processes, ideas) and disseminate, i.e. use in practice. It is possible thanks to the improvement of the relationship with the environment, the enterprises using different methods of stimulating new ideas and creativity in the employees.

\section{N O T E S}

${ }^{1}$ Competences are considered as the competences of discovery, incubation and acceleration as well as commercialisation.

${ }^{2}$ For example, customer resistance and government are considered part of the first group, while an undeveloped network and ecosystem, technological turbulences and an improper system are considered as obstacles in the macro environment.

\section{R E F E R E N C E S}

Brem, A. (2011), Linking Innovation and Entrepreneurship - literature Overview and the Introduction of a Process-Oriented framework, "International Journal of Entrepreneurship and Innovation Management" vol. 14(1). DOI: 10.1504/IJEIM.2011.040820 [Accessed: 06.09.2018]

Cassamatta, C. (2003), Financing and advising: optimal financial contracts with venture capitalists, "The Journal of Finance" vol. 58(5). DOI: 10.1111/15406261.00597 [Accessed 16.09.2018].

D'Este, P., Lammarino, S., Savona, M., Tunzelmann, N. (2012), What hampers innovation? Revealed barriers versus deterring barriers, "Research Policy" vol. 41. DOI: 10.1016/j.respol.2011.09.008 [Accessed 16.09.2018]. 
Drucker, P.F. (1992), Innowacje i przedsiębiorczość. Praktyka i zasady, PWE, Warszawa.

Du Preez, N., Louw, L., Essmann, H. (2014), An Innovation Process Model for Improving Innovation Capability, "Journal of High Technology Management Research" vol. 26, http://www.researchgate.net/publica-tion/266444507 [Accessed 06.09.2018]

Dymitrowski, A. (2014), The Role of Innovations. Created in the Internationalization Process for Company Performance, PWN, Warszawa.

Działalność innowacyjna przedsiębiorstw w latach 2014-2016, (2017) Główny Urząd Statystyczny i Urząd Statystyczny w Szczecinie, Warszawa, Szczecin.

Działalność innowacyjna przedsiębiorstw w latach 2012-2014 (2015), Główny Urząd Statystyczny i Urząd Statystyczny w Szczecinie, Warszawa.

Ettlie, J.E. (2000), Managing Technological Innovation, John Wiley \& Sons, New York.

Handbook: Jak wdrażać innowacje, Infuture hatalska foresight institute, Gdańsk 2018.

Hölzl, W., Janger, J., (2014), Distance to the frontier and the perception of innovation barriers across European countries, "Research Policy" vol. 43(4). DOI: 10.1016/j.respol.2013.10.001 [Accessed 20.09.2018].

Hölzl, W., Janger, J. (2011), Innovation barriers across firm types and countries. Proceedings of the DIME Final Conference, 6-8 April 2011, Maastricht. WIFO.

Larsen, P., Lewis, A. (2007), How award-winning SMEs manage the barriers to Innovation, "Blackwell Publishing" vol. 16(2). DOI: 10.1111/j.14678691.2007.00428.x [Accessed 16.09.2018].

Lian, J.W., Yen, D.C. (2013), To buy or not to buy experience goods online: Perspective of innovation adoption barriers, "Computers in Human Behavior" vol. 29. DOI: 10.1016/j.chb.2012.10.009 [Accessed 13.09.2018].

Maldonado-Guzmán, G., Garza-Reyes, J.A., Pinzón-Castro, S.Y., Kumar, V. (2017), Barriers to innovation in service SMEs: evidence from Mexico, "Industrial Management \& Data Systems" vol. 117(8). DOI: 10.1108/IMDS-082016-0339

Pellegrino, G., Savona, M. (2017), No money, no honey? Financial versus knowledge and demand constraints to innovation, "Research Policy" vol. 46, DOI: 10.1016/j.respol.2017.01.001 [Accessed 15.08.2018].

Rothwell, R. (1992), Successful Industrial Innovation: Critical Factors for the 1990s, "R\&D Management" vol. 22(3).

Sandberg, B., Aarikka-Stenroos, L. (2014), What makes it so difficult? A systematic review on barriers to radical innovation, "Industrial Marketing Management" vol. 43(8), DOI: 10.1016/j.indmarman.2014.08.003 [Accessed 16.09.2018].

Schmookler, J. (1966), Invention and Economic Growth, Harvard University Press, Cambridge, Massachusetts. 
Barriers to creating innovation in the polish economy in the years 2012-2016

Sitkowska, R. (2006), Potencjał innowacyjny firmy i jego czynniki, [w:] Innowacje. Kształcenie. Zarządzanie, red. J. Bućko, Państwowy Instytut Badawczy, Radom.

Zastempowski, M. (2010), Uwarunkowania budowy potencjału innowacyjnego polskich małych i średnich przedsiębiorstw, Wydawnictwo Naukowe Uniwersytetu Mikołaja Kopernika, Toruń.

Zielińska-Głębocka, A. (1996), Handel krajów uprzemysłowionych w świetle teorii handlu międzynarodowego, Uniwersytet Gdański, Gdańsk. 